\title{
A Stone Structure Dated 827 AH /1424 AD in Kokand, Central Asia: A Study on Form and Content
}

\author{
Noha Gamil \\ Islamic dept., Faculty of Archaeology, Cairo Univ. \\ nohaghaly51@yahoo.com
}

\begin{abstract}
The present paper studies and publishes a stone structure in the northern part of Madina Cemetry, July Stan Sisca St., No.2, Kokand in Central Asia. This stone dates back to 827 $\mathrm{AH} / 1424 \mathrm{AD}$ and is in good condition except for the internal surface with obliterated inscriptions. The inscriptions on the structure help identify the name and date of death of the owner. The paper describes and studies the structure analytically in terms of font shape, style of inscribing letters, inscribing words, and content of inscriptions. In Central Asia, calligraphers inscribed many writings on various buildings, including Quran verses, Prophetic Hadiths, prayers, and poems. They also used to create funeral inscriptions on tombstones and coffins of different shapes. According to the archaeological literature, calligraphers used different materials, which illustrated the development of such writings that included recording inscriptions and honorary and functional titles and suggested strong ties among the parts of the Islamic World. The present study highlights the content, significance, font type, and features of an inscription.
\end{abstract}

Keywords: Stone, Dakhma, Kokand, Central Asia, Decorative Elements, Persian Pottery

\section{Introduction}

The stone structure (Plate 1) is above two rectangular marble bases in the outer area of the mausoleum of Dakhma Shaykhoun, Kokand (Al-Hamawi, 1906)(Junnaydulla khan, 1991) (Alafify, 2000) (Igamberdiev, Amirasaidov, 2007) (Ogohiy, 2009) (Bababekov, 2011 ) (Roshdy, 2014) in Central Asia (Pugachenko, 1983) (Partold, 1996). It is a one-level structure of limestone (Obaid, 2007) that measures $218 \mathrm{~cm}$ long, $56 \mathrm{~cm}$ wide, and $74 \mathrm{~cm}$ high. 


\section{Inscription ${ }^{1}$}

2.1. Inscriptions of the long northern side (Figure1) (Plates 1A, 1B, 1C, 1D , 1E, 1F)

The inscriptions were carried out in high relief in three equal horizontal lines using Jeli Thuluth script. They were void of decorative elements. They read:

\section{Line One}

When I felt grief, I experienced discomfort. Alas! All living people passed away sadly. Eyes shall lament the orchard because its towering cypresses had gone.

$$
\begin{aligned}
& \text { دردى به دل رسيد كه آرام جان برفت وان هر كه در جهان به دريغ از جهان برفت بالا تمام كر ده درخت }
\end{aligned}
$$

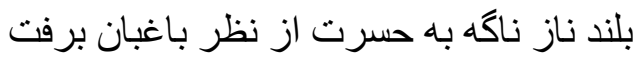

$$
\begin{aligned}
& \text { أصيب قلبي بالهم ففارقت الراحة روحي ، و أسفاه فكل من كان بالدنيا رحل عنها بحسرة يحق لعين العين أن } \\
& \text { تبكي نائحة على البستان فقد زال سرو ها السامق لوفي }
\end{aligned}
$$

\section{Line Two}

The tree rose high and smooth until it was complete. Suddenly, it disappeared from the gardener's view. We were wounded deeply. So that we couldn't bleed any sigh. What pain we had!

$$
\begin{aligned}
& \text { شايد كه جشم جشمه بكريد به هاى هاى بر بوستان كه سرو بلند از ميان برفت خورديم زخمها كه نه خون }
\end{aligned}
$$

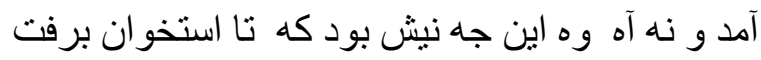

$$
\begin{aligned}
& \text { تعالت الثجرة العالية التنعيم حتي اكتملت وفجأه غابت عن نظر البستاني، أصابتنا الجراح حتى لم يبدر منا } \\
& \text { دماً أو آهه فأي ألم هذا وصل حتى النخاع }
\end{aligned}
$$

\section{Line Three}

A man goes like piercing lightning. A spring and light for his family and clan. I felt deep sorrow, and my heart bled when this newly-grown cypress passed away.

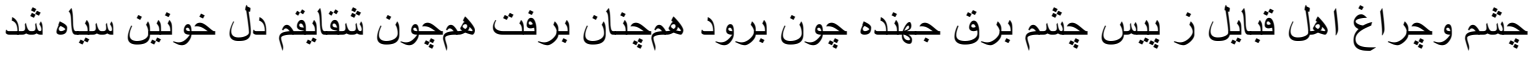

$$
\begin{aligned}
& \text { كان سرو نوبر آمده از بوستان برفت }
\end{aligned}
$$

${ }^{1}$ I would like thanks Dr Mahmoud Roshdy Assistant Professor, Faculty of Archaeology, Cairo University for Photographing A Stone Structure under study.

I would like thanks Dr Sherin Sayed Lecturer Department of Oriental Languages, Faculty of Arts, Shams University, in translating text from Persian to Arabic 


\section{A Stone Structure Dated 827 AH /1424 AD in Kokand, Central Asia: A Study} on Form and Content

رحل كالبرق الثاقب حين يمضي أمام العين هذا المعين والضياء لآهله وعشيرته كذلك اسودت شقائق قلبي

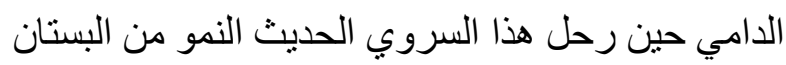

2.2. Inscriptions of the long southern side (Figure2) (Plates 2, 2A, 2B, 2C, 2D , 2E,2F)

This side resembles the northern one in terms of form. Additionally, the content of the inscription includes Rubā $\overline{1}$ Persian in high relief.

\section{Line One}

O pampered cypress in the garden, the heaven is your place, $O$ pure soul, the heaven is your place, $\mathrm{O}$ pure soul, may God bless your tomb and give you a fragrant smell (as if) your death is like a master in heaven.

اي سرو ناز كلثن فردوس جاى تست اى روح محض جنت على سراى تست اي نفس باك منزل خاكت

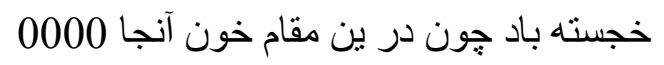
أيها السرو المدلل في الروضه، الجنة مكانك أيتها الروح الطاهره، جنة علي هي مكانك أيتها النفس الطاهره،

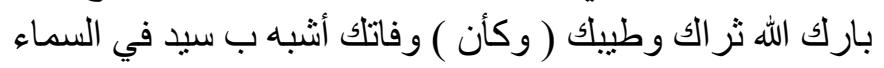

\section{Line Two}

At the due time, blood felt from the cypress. Do not regret a large knife that hit you, our cry as we lamented you world wide. O Lord, bestow your infinite mercy on this drowned person.

$$
\begin{aligned}
& \text { از صرصر اجل قد خون سرو ازت فتاد حسرت مبر كه به ساطور براى تست وفات تو سيد در آسمان در } \\
& \text { كوش جر خ غلغله ما تست } \\
& \text { في مو عد الأجل ، تساقطت الدماء من السرو لاتتدم على سكين كبير قد أصابك لقد ارتفع صر اخنا ( عليك ) في }
\end{aligned}
$$

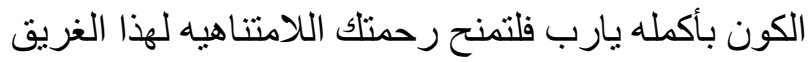

\section{Line Three}

Your role is clear for the creatures and the universe convoy "beings" ..... Your kindness and mercy are endless ......

$$
\text { نقشت ز بيس جشم خلايق مى رود كاروان كائنات 0000يارب ز غريق رحمت بي منتهاش كن.......... }
$$




\subsection{Inscriptions of the short western side (Figure 3) (plate 3)}

It includes an inscription carried out in high relief in three Arabic horizontal lines using Thuluth script. The lines read:

Line One: The death of Amir Nosherwân

$$
\text { وفات أمير نوشيروان }
$$

Line Two: Ibn Amir Darwish

$$
\text { بن امير درويش }
$$

Line Three: On this twenty-seventh

$$
\text { في تاريخ سبع عشرين }
$$

\subsection{Inscriptions of the short eastern side (Figure 4) (plate 4)}

It includes an inscription carried out in high relief in one Arabic horizontal line using Jeli Thuluth script. The rest of the side is decorated with decorative elements to highlight the similarity between both sides. The inscription reads

And eighth Hijri

$$
\text { وثمانمايه الهجريه }
$$

\subsection{Internal surface (Plates 5, 5A , 5B , 5C , 5D )}

The internal surface of the construction encompasses vertical rectangular areas. The upper and lower parts are similar, but the middle is different in terms of form and content as follows:

The upper vertical area is divided into two parts. The first part is a square containing a rhombus with an obliterated inscription. The remaining part of the inscription shows that it was implemented in square Kufic script. The four corners of the rhombus are adorned with triple leaves, resembling the lower ones.

The middle area (a rectangular entrance with a lobbed arch) is adorned with rectangular vertical ribbons. The spandrels have simple floral motifs of leaves and two multi-petal flowers. Vertical and horizontal ribbons encompass the vertical rectangular areas with an obliterated inscription whose remaining part shows that it is a part of Persian poetry in Jeli Thuluth in high relief. 


\section{A Stone Structure Dated 827 AH /1424 AD in Kokand, Central Asia: A Study on Form and Content}

\section{Analytical Study}

\subsection{Form}

The inscription was carried out in Jeli Thuluth (Al-Qalqashandi, 1913) (Fadaely, 2006) (Arslan, 2007) as a variety of Thuluth. Jeli is the last stage of the development of Thuluth that underwent four stages, starting with Aqdam Thuluth. In Jeli Thuluth, calligraphers could combine the characteristics of Thuluth (Obaid, 2005) and Jeli, namely flexibility of structure, big letters, and strong mushabaa letters (Obaid and Helal, 2013). The Jeli is also thicker because it is the last stage of developing the Thuluth. It often takes the form of as tacked or overlapped row. The letters and words are stacked in a way that shows the line as levels(two to three) according to some rules. This form is not hard to read. On the contrary, the Thuluth is generally written in a lined form (Magdy, 2018).

The Jeli was used besides the Thuluth in the Timurid era, as shown in the early models of the tomb structures. Later in the same age, it was the most common. Thus, the Jeli Thuluth examples in late periods was an extension of the development of the Thuluth and an accurate application of its criteria. Moreover, this script appeared clearly while maintaining the structures between letters in many positions and implementing the letter clearly in the texts. The implemented Jeli Thuluth on the structure understudy resembled a stage of developing the Thuluth in Central Asia, as shown in many structures of the Timurid princes and princesses in the 8th9th H./14th-15th centuries, such as Emir Zadeh Muhammad Sultan (806 AH, 1404 AD) (plate 6, 6A), Emir Emir Hamza Ibn Tugha Bugha (833 AH, 1429 AD) (plate 7 ), and Sultan Ibrahim Bahader Ibn Jahan Shah (838 AH, 1434 AD) (plate 8 ) (Magdy, 2018)

The Thuluth was one of the most common scripts in implementing funeral inscriptions in Central Asia. It accounted for $85 \%$ of the used scripts. It was developed by the $9^{\text {th }}$ H./ $15^{\text {th }}$ G. century (Obaid, 2007).

The Jeli Thuluth came next after the Kufic script in terms of the wide spread use on the buildings of the Timurid (771-906 AH./ 1369-1500AD.) in Samarkand. For example, it was used in the writing line of the eastern entrance on the southern façade of the complex of Gur-e-Amir (807-808AH./ 1404-1405AD.) and the foundation text of the mosque of Gur-e-Amir. It continued in the Shaybanids (9061006AH./1500-1598AD.), such as the foundation text ofKojkunji Khan Mosque, 
Registan Square, Samarkand. By the late Shaybanids, the JeliThuluth was not as accurate and precise as the Timurid dynasty (Magdy, 2018).

\section{Writing Features of the Structure}

The words were distributed evenly on the structure. They were 30 to 33 on every line of the long sides separated by apparent horizontal dividers between the lines. The short sides contained three to four words with apparent horizontal dividers between the lines. Some words overlapped, including Sayed (master) and Djushma. Sometimes, the final syllables of some words were written above the final syllables, such as Derdy, Bervet, Khordim, and Sarsar. Some letters overlapped their words, e.g., tā', wāw, nūn, qāf, kāf, and hā' .

There was a simple inclination at the end of the structure. Thus, the ending words of the lines were unequal. However, the writing of words was not affected.

Words were big and thick. Thus, the inscription was easily identified and read.

Some letters were not obliterated, such as Jeem and similar letters, șād and $d \bar{a} d, t \underline{a}$ and $z \bar{a}^{\prime}, f \bar{a}^{\prime}, q \bar{a} f, m \bar{\imath} m$, and $w \bar{a} w$.

All spaces were filled using case markers, points of i'jam (Persian), and simple decorations, such as heart-like, almond-like, and simple three-fold leaves.

\section{Analyzing the Letters of the Structure ( Figure5)}

In this section, we illustrate the forms of inscribing the letters on the coffin's structure understudy.

'alif: It took the mutlaq and saeed (upward)

$\boldsymbol{B} \overline{\boldsymbol{a}}$ ' and similar letters: It took the mabsota (extended) form.

Jeem and similar letters: It took different forms, such as the attached, irtiqaa (upward), muhalaqa (sphere), molowaza (almond-like), and beginning extended.

Däl and dhäl: They took the attached, muktalasa, makhtofaa, mosha'ra forms

$\boldsymbol{R} \overline{\boldsymbol{a}}^{\prime}$ and $z \overline{\boldsymbol{a}} \boldsymbol{y}$ : They took the hanged and extended forms. 
Sin and shin: The sin is written with and without asnan, lit. teeth (upper parts). In the inscription, it took the form with teeth that was more common. It was separated and attached.

șa $\mathbf{d}$ and $\boldsymbol{d} \overline{\boldsymbol{a}} \boldsymbol{d}$ : They have heads and cups. The latter resemble those of the sin and shin. These letters are attached to the next letter with a curved part. In the inscription, they took the compound and middle forms.

$t \bar{a}^{\prime}$ and $z \bar{a}$ : They were inscribed in the malfofa (twisted) compound form.

'ayn and ghayn: They took the attached, open square, lease square, and attached beginning forms.

$f \bar{a}^{\prime}$ and $q \bar{a} f:$ They took the attached, mawqofa (separated), and molowaza(almondlike) forms.

Käf: It took different forms, such as the mabsota (compound extended), hanged, moaraamobtada (beginning compound strip), and middle compound strip.

Läm: It was inscribed in the final attached and middle compound forms.

Mìm: It was inscribed in the mualaqa(hanged), mukhafafa (thin), muhalaqa (with a cycle), and maqluba (inverted) forms.

Nün: It was inscribed in the combined and mualaqa(hanged) forms.

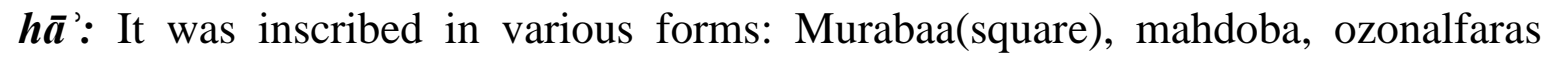
(horse's ear), and with two șāds.

$\boldsymbol{W} \overline{\boldsymbol{a}} \boldsymbol{w}$ : It was inscribed in various forms, including the attached, mabsutih, Mushara, and Muqawara.

$\boldsymbol{y} \overline{\boldsymbol{a}}$ : It was inscribed in the rajea (isolated) and attached forms.

\section{Content}

The inscription understudy included different contents, including recording inscriptions of the name of the deceased, date of death, and Persian poetry (Ruba' $i$ ). 


\subsection{Recording Inscriptions}

Recording inscriptions played a significant and important role on the structure, including the name of the deceased (Emir Anosherwan ibn Emir Darwish) and the date of death, which the inscriber was keen on recording very precisely by writing the year (Hijri) in letters. The inscription reads in twenty-seven and eight hundred Hijri year.

Anosherwan belonged to the Timurid Dynasty as he was a member of the Barlas Dynasty. He lived in Samarkand in the era of Emir Timur. When Shah Rakh Merza reigned and moved the capital to Herat, Amir Darweesh moved to and settled in Kokand in 822AH /1419AD until he died in 827AH / 1424AD. Because of the prevalence of Persian in that region, Emir Darweesh was known as "Anosherwan" because of the influence of Persian names, such as Khosrow I who was known as Anosherwan the Just (أنوشيرو اندادكر).

Emir was used on buildings and coffins as an honorary title for many people with a distinguished social status who did not reign but belonged to some famous dynasties in the region, such as Emir Hussain Ibn Qaraqtlag, as shown in the foundation text of the funeral dome of "Tgltkin" in the Shah Zandah Complex, Samarkand.

\subsection{Persian Pottery}

The structure contained the Persian Ruba' $i$ as a lament of Emir Anosherwan. The Persian Ruba $i$ is written as a four-line (or two-couplet) poem, with a rhyme in the first, second, and fourth. The rhyme of the third is either added or neglected. In the case of rhyming all lines, it is called "complete Ruba $i$ " to differentiate it from the "incomplete (Khasi) one, in which the third rhyme is neglected (Moawad, 1983) (Obaid, 2012).

The poetic content inscribed on the long sides of the structure was related clearly to it. Persian poetry was more common than Arabic on such structures because Persian was the language of culture and literature in this region and the surrounding areas. On this structure, lament meanings were quotes of the lament of Saadeldeen Shirazi (Hendawi, 1951) (Feroghi, 2002) (Almalki, 2014). The lines conveyed the same content, namely the lament of the deceased. They were implemented in Thuluth in high relief. Therefore, they were used on structures, such as the middle section of the long side of the structure of Abu Al-Ma'ali bin Abi Al-Hassan Ali bin Muhammad bin Alaa Almalik (Obaid, 2007), the structure of Siobing Muhammad bin Sultan bin Quebec- Sultan of Dokhma Shaykhoun in Samarkand, and the 
surface writings of the structure of Bakhtiar Sultan Bajhel Dekhtaran (Babakhan, 2011 )

\section{Decorative Elements (Figure6)}

The structure understudy was decorated with some decorative elements in different parts. These decorative elements were primarily floral. They were sometimes almond shapes with emerging simple leaves in the middle of the inscription. They also included almond shapes out of half-palmettes with emerging bud, three-fold, and fivefold leaves. The internal surface of the structure was also decorated with multi-petal small flowers. Sometimes, geometric shapes, i.e., squares and rectangles, were implemented.

\section{Conclusion}

1- The study was carried on reading and analyzing the structure's inscription understudy content that has not been published before.

2- The study affirmed that marble was the material for making the structure because it was available in that mountain region. After all, there were many quarries from which marble was brought.

3- The study concluded that the inscription was carried out in the Jeli Thuluth that peaked by the 9th H./15th G. century and widely spread on the buildings and tombs' structures of the Timurid dynasty.

4- The study illustrated that Persian was the language used in implementing the inscription on the structure. The content of the Ruba ' $i$ Persian poetry related to the coffin on which it was inscribed because it expressed lament.

5- The study showed that the owner's name, social status, and date of death were in Arabic letters. The inscriber defined the type of calendar as Hijri.

6- The study affirmed that Emir Darweesh Anosherwan belonged to the Timurid Dynasty as he was a member of the Barlas Dynasty, lived in Samarkand, and was buried in Kokand.

7- The study illustrated the interest of the inscriber in the decorative pattern as he implemented some simple floral decorations. 


\section{References}

- Alafify (Abdulhakim), Mawsow'at 1000 Madinah Islamiah (Encyclopedia of 1000 Islamic Cities), $1^{\text {st }}$ ed., Beirut, 2000, p.219.

- Al-Hamawi (Yaqut), Mu'jam al-Buldān (Dictionary of Countries), Part 2, $1^{\text {st }}$ ed., Saada Press, Cairo, 1906, p.480.

- Almalki (Sobeh) \& Alabasy (Emadeldeen), Altanasu Bayn A'hd Alamam Ali Ela Malik Alashtir Wa-lrisalih Alkhamisahi (Fi Nasihat Almuluk) Lisaeda aAlshiyrazi (Intertextuality between the covenant of Imam Ali to Malik al-Ashtar and the Fifth Message (On Advice to Kings) by Saadi al-Shirazi), Babylon Journal of Humanities, Vol. 22, Issue 2, 2014, pp. 296-297.

- Al-Qalqashandi (Ahmed), Șubh al-A sháfísināa 'at al-Inshā' ('Daybreak for the Night-Blind regarding the Composition), Alilmia Press, Beirut, 1913, part 3, p. 55.

- Arslan (Aly), Arabic Calligraphy of the Turks (trans. SohailSaban), Darah Journal, Issue 1, 2007, p. 219.

- Bababekov ( Khaydarbe ), The history of Kokand, Tashkent, 2011, p 5.

- Babakhan (Bekhtear), Momen (Ashur Bey), Jürgen Powell, the Tombstones of the Shayban Dynasty (Khanate of the Uzbeks), Wasbedan, 1997, pp 17,18.

- Fadaely (Habib-Allah), Atlas Alkhatwa-lkhtut (Atlas of Calligraphy and Scripts) (trans. Mohamed Altounju), $2^{\text {nd }}$ ed., Dar Talas, Damascus, 2006, p.266.

- Feroghi (Intikhab), Wise Sayings of Saadi(trans. Mohamed Alaaeldeen), $1^{\text {st }}$ ed., 2002, pp.5-6

- Hendawi (Mohamed), Saad eldeen Alshirazi, Shaeer Alinsania (asroh, hayatouh, diwanouh "albostan") (Saade ldeen Shirazi: Poet of Humanity (His Age, Biography, and Divan "Albostan")), Egypt Misr, 1951.

- Igamberdiev ( A.), Amirasaidov ( A.), history of Kokand khanate $18^{\text {th }}$ century 1876 bibliography with illustrations , Tashkent , 2007, p. $131: 144$

- Junnaydullakhan ( Ishaqkhan ), The history of Fergana,Tashkent, 1991, p 285.

- Magdy (Maha), Inscriptions on stone and marble structures in the Timurid and Shaybani periods $(771-1008 \mathrm{H} / 1369-1599 \mathrm{M})$ In the cities of Samarkand and Shahrsabz, Artistic archaeological study, [MS.dissertation], Faculty of Archaeology, Cairo University, 2018, p. 43,73,276,277,287.

- Moawad (Ahmed), Alwan min AlshearAlfarsi (Examples of Persian Poetry) $1^{\text {st }}$ ed., Cairo, 1983, p.169. 
- Obaid (Shebl), Alnoqosh Al'inshaia'a fi Madinat Samarqand wa Ahmyatya Alatharya (Architectural Inscriptions in Samarkand and their Archaeological Importance, Proceedings of the Conference of the Faculty of Arts, Minia University, 2005 p 1:25.

- Obaid (Shebl), Noqush Altawabit Alhajaria Wa-lrukhamia Bi-madinatay ShahrSabz Wa-samirqand fi Flfatrah Almumtadah min Alruba Althaani min Alqarn Altaasie Alhijrii / Alkhamis A'shar Almiladii, Wa-hataa Alrubue Al'awal min Alqarn Alhadi A'shar Alhijriil Alsaabie A'shar Almiladii (Dirasih Atharih Faniya)(Inscriptions of Stone and Marble Coffins in ShahrSabz and Samarkand from the Second Quarter of the $9^{\text {th }}$ H./ $15^{\text {th }}$ G. Century to the First Quarter of the $11^{\text {th }}$ H./ $17^{\text {th }}$ G. Century (An Artistic Archaeological Study), Abgad Journal, Vol. 2, 2007, p. 115.

- Obaid (Shebl), Diwan Al khat Al arbi (Diwan Al-line Al-Arabi), Alexandria, 2012, P. 72.

- Obaid (Shebl) and Helal (Karim), Naqsh Waqfy Mwrkh Bi-sanat $2311 \mathrm{~h} / 0271 \mathrm{~m}$ bi-Madrasat Shyrghazy Khan fi Khywa (An Endowment Inscription in Sherghazi Madrassa in Khiva, Journal of Tourism and Antiques, Issue 2, 2013, p. 216.

- Ogohiy (Muhammad), Zubdat eltawariykh- the important aspects of history, Tashkent, Uzbekistan , 2009, p. 80.

- Partold, W. History of the Turks in Central Asia (trans Ahmed Alsaeed Soliman), General Egyptian Book Organization, 1996, p.7.

- Roshdy (Mahmoud), 'ema'er Alekhaneyyen Alebaqeyh fey Madinat Khawqand Be wadey Ferghanh Derasah Athareyh M'emareyh (Remaining Buildings of the Khanates in Kokand, Ferghana: An Archaeological Architectural Study [Ph.D. dissertation], Faculty of Archaeology, Cairo University, 2014, p. 6:29 


\section{Figures}

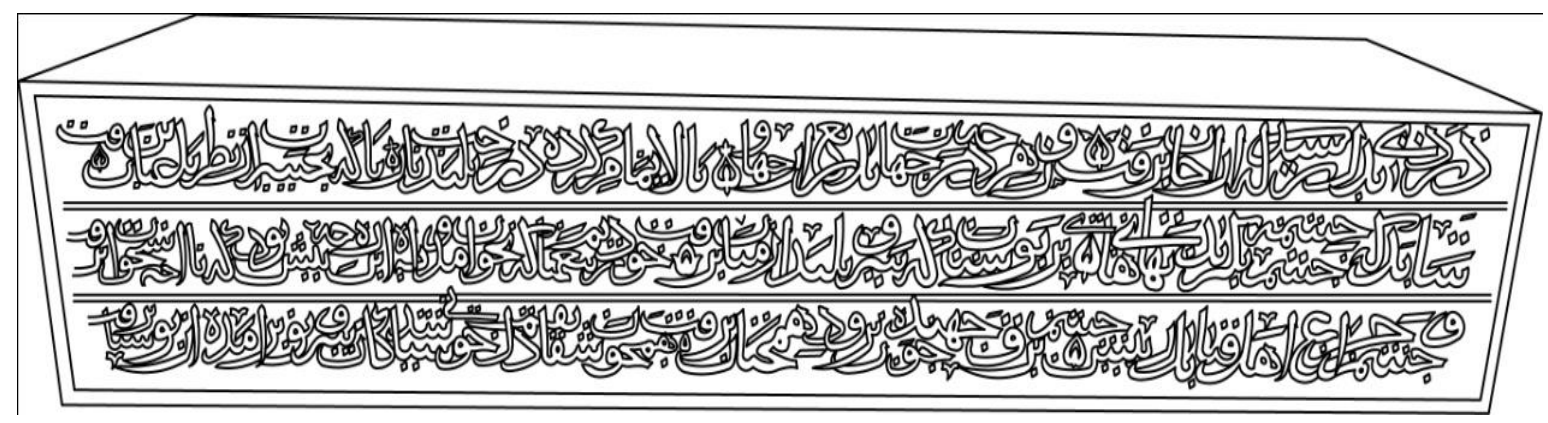

Fig. (1): The long northern side of the structure

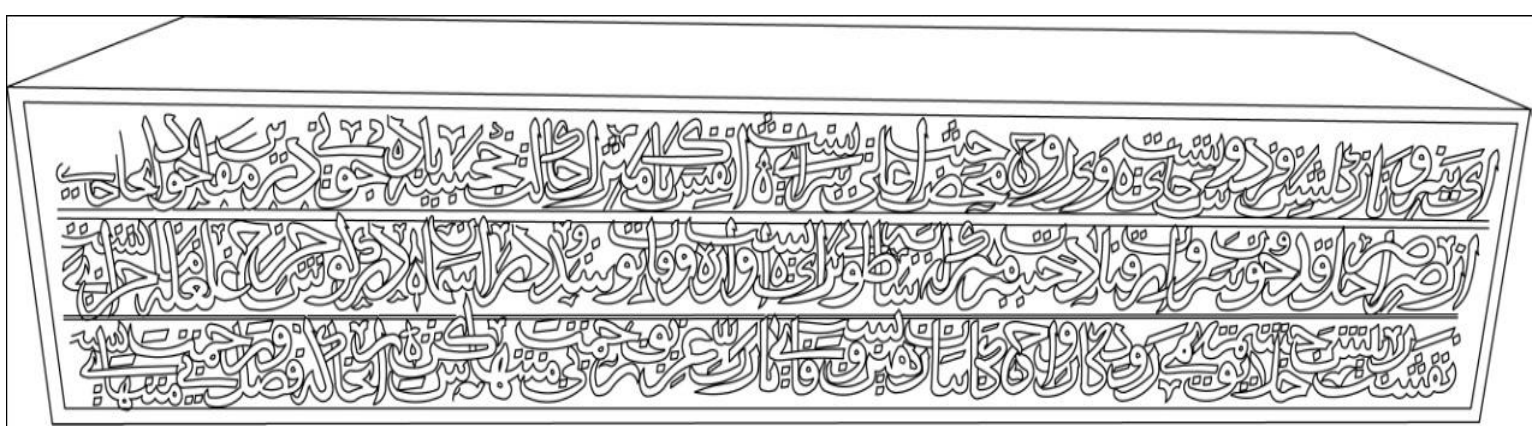

Fig. (2): The long southern side of the structure

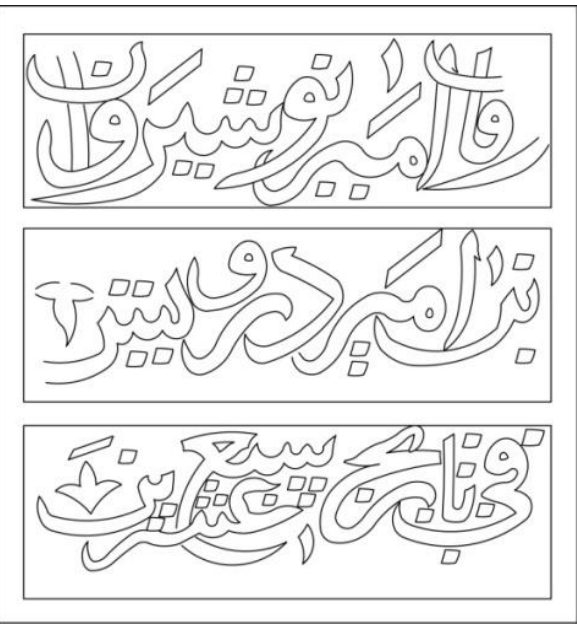

Fig. (3): the short western side 
A Stone Structure Dated 827 AH /1424 AD in Kokand, Central Asia: A Study on Form and Content

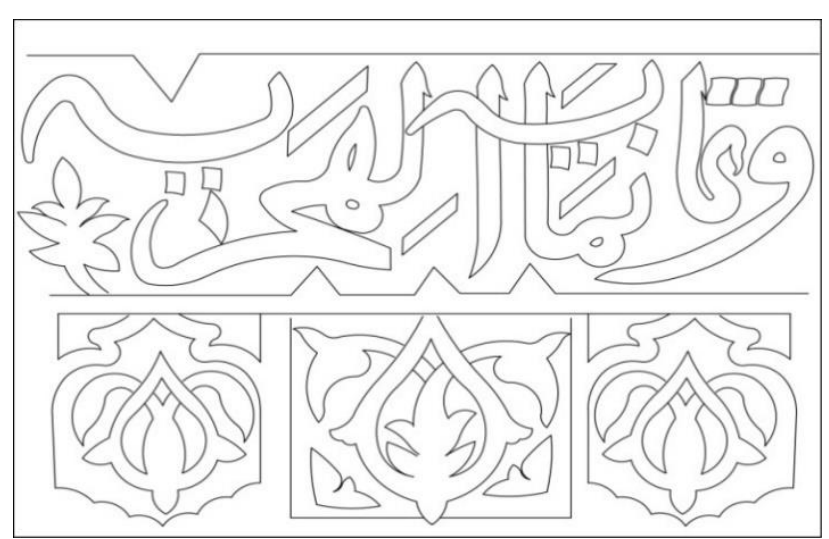

Fig. (4): The short eastern side of the structure

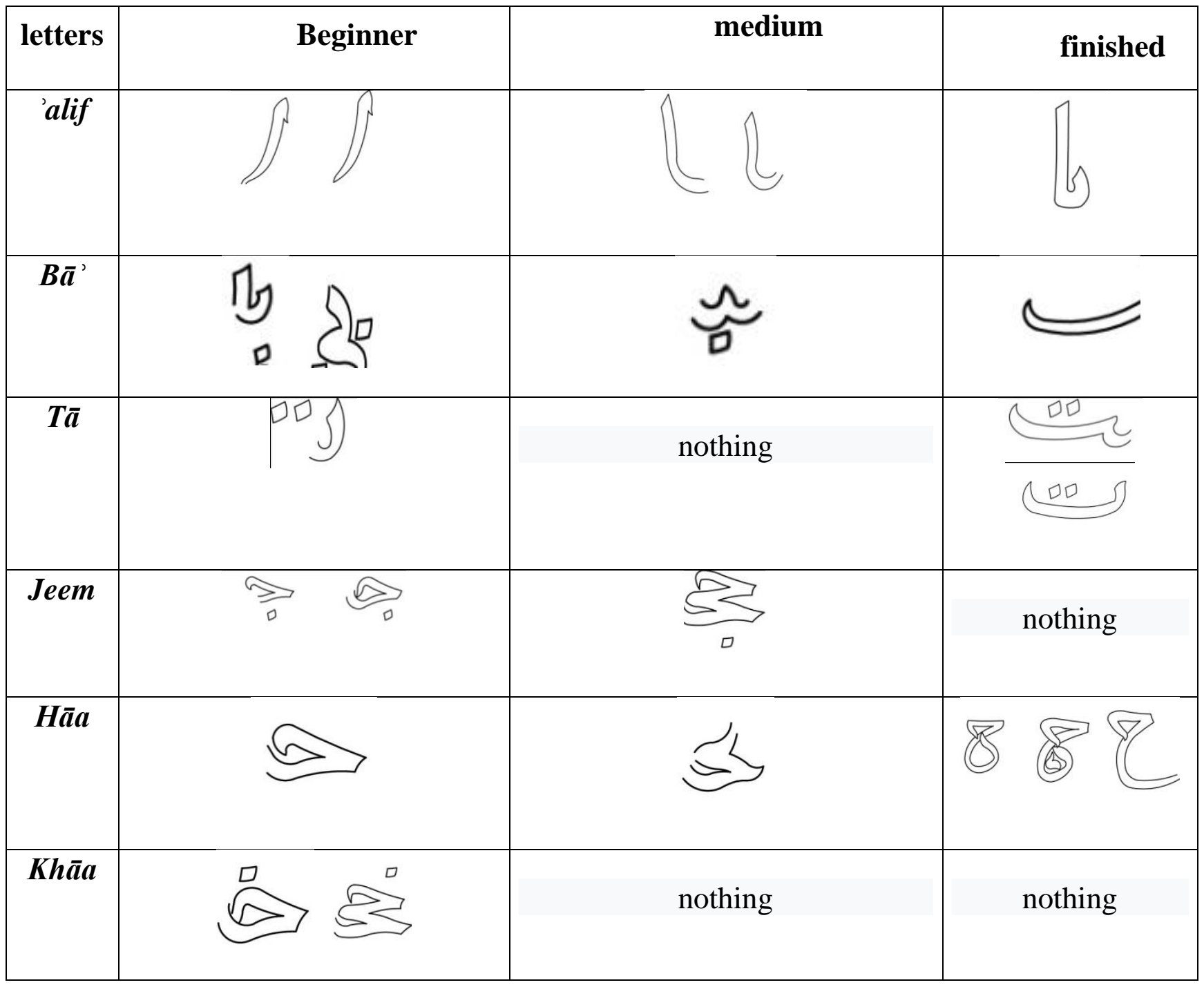


JOURNAL OF THE FACULTY OF ARCHAEOLOGY -VOLUME 25 -2022

\begin{tabular}{|c|c|c|c|}
\hline$\overline{D a} l$ & $S$ & $S \frac{\lambda}{\Omega \Omega}$ & $S$ \\
\hline$R \bar{a}^{\prime}$ & NAS & ) & $a \mathscr{r} r$ \\
\hline Shīn & 总 & i & 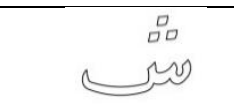 \\
\hline șâd & 20 & 20 & Nothing \\
\hline$d \bar{a} d$ & nothing & nothing & $\Leftrightarrow 8$ \\
\hline$t \bar{a}$ & nothing & & Nothing \\
\hline$z \bar{a}$ & nothing & & Nothing \\
\hline 'ayn & $\sqrt{5} \sqrt{\theta}$ & nothing & \\
\hline Ghayn & nothing & 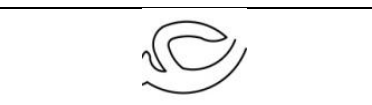 & \\
\hline$f \bar{a}^{\prime}$ & (9) & (马) $\stackrel{0}{\Omega}$ & nothing \\
\hline$Q \bar{a} f$ & (9) & $\underbrace{\rho}$ & r \\
\hline$K \bar{a} f$ & 5 级 汤 & $\Leftrightarrow \Leftrightarrow$ & 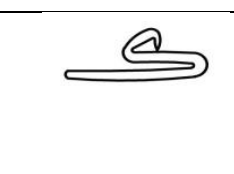 \\
\hline
\end{tabular}




\section{A Stone Structure Dated 827 AH /1424 AD in Kokand, Central Asia: A Study on Form and Content}

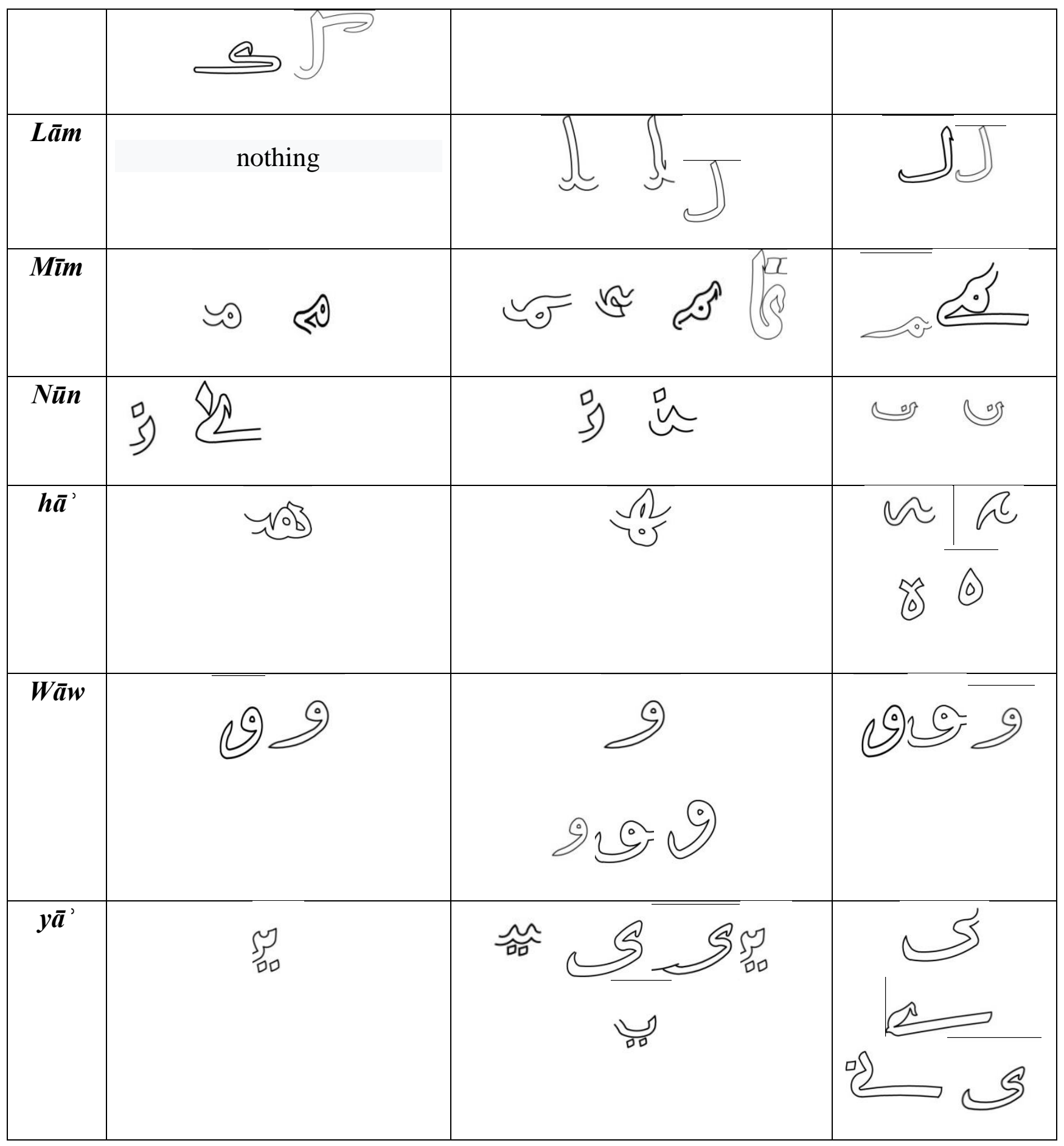

Fig. (5): Analyzing the Letters of the Structure 

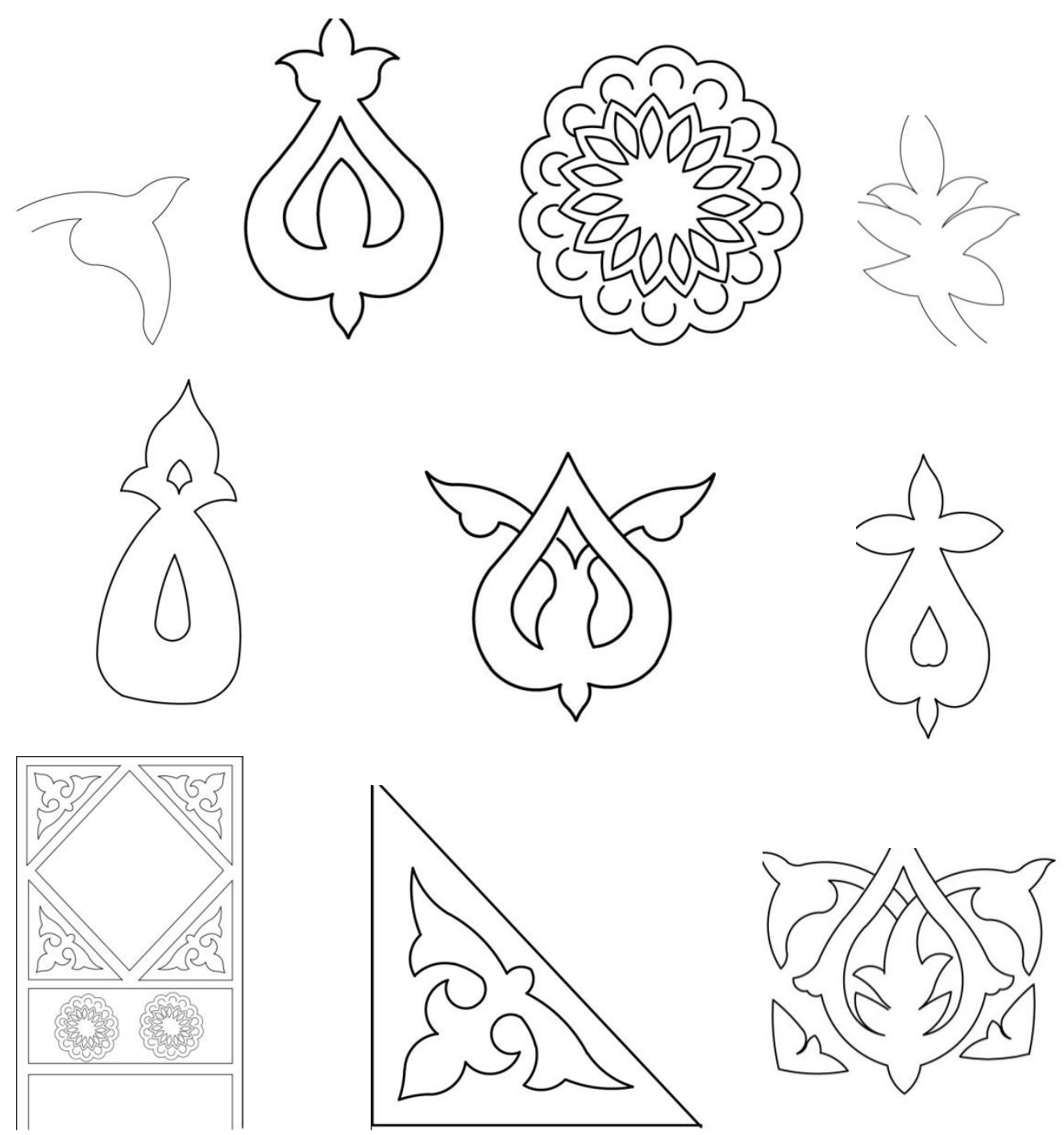

Fig. (6): Decorative elements of the structure 
A Stone Structure Dated 827 AH /1424 AD in Kokand, Central Asia: A Study on Form and Content

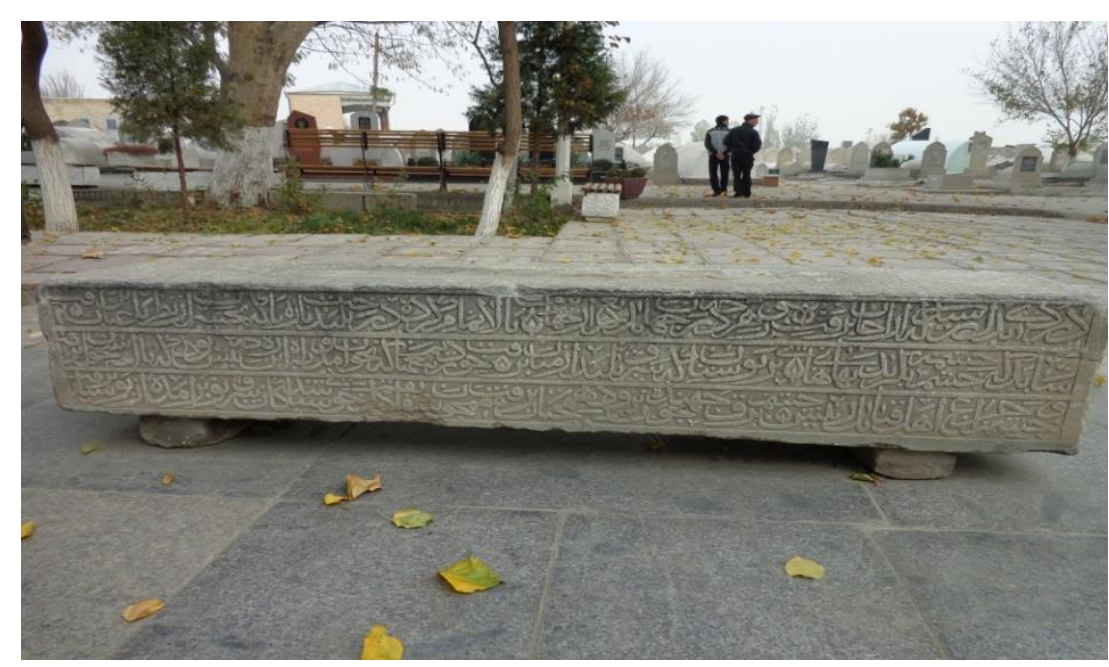

Pl. (1) A stone coffin in the square of the burial dome of Dokhma Shaykhoun

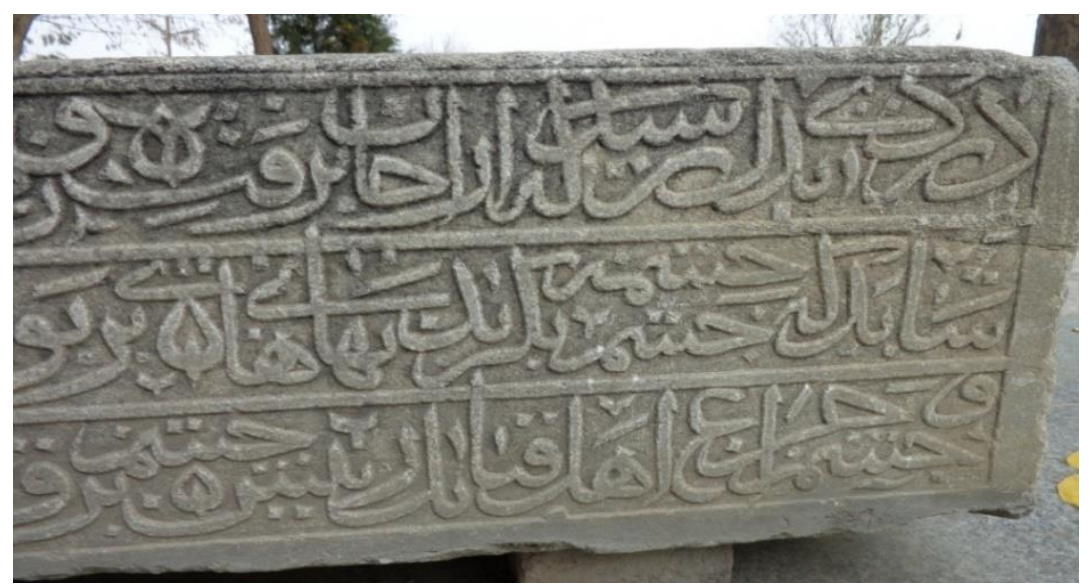

Pl. (1A): Details of the inscription on the long northern side of the stone structure

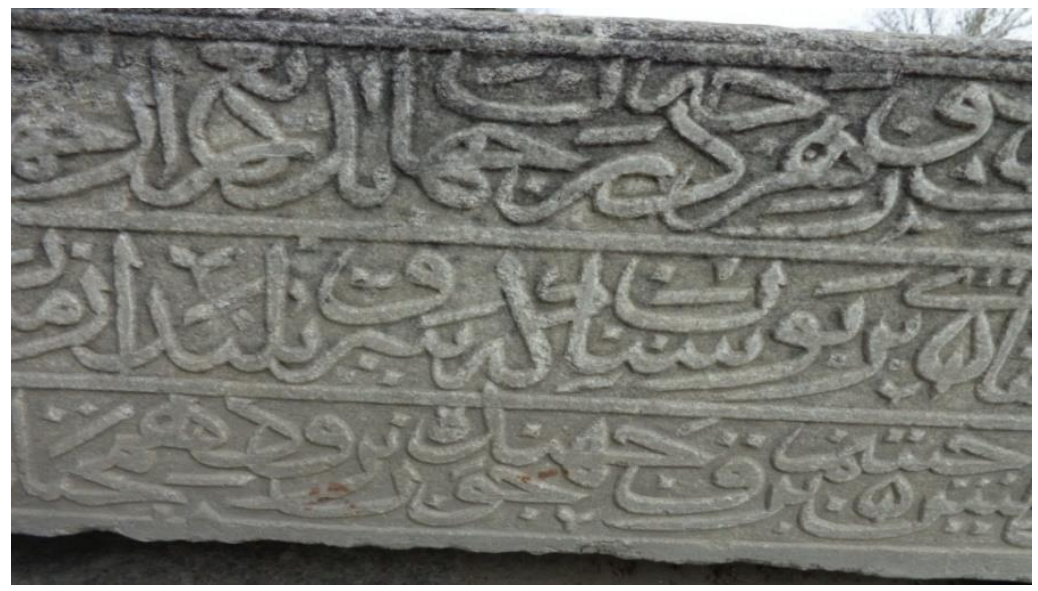

Pl. (1B): Details of the inscription on the long northern side of the stone structure 


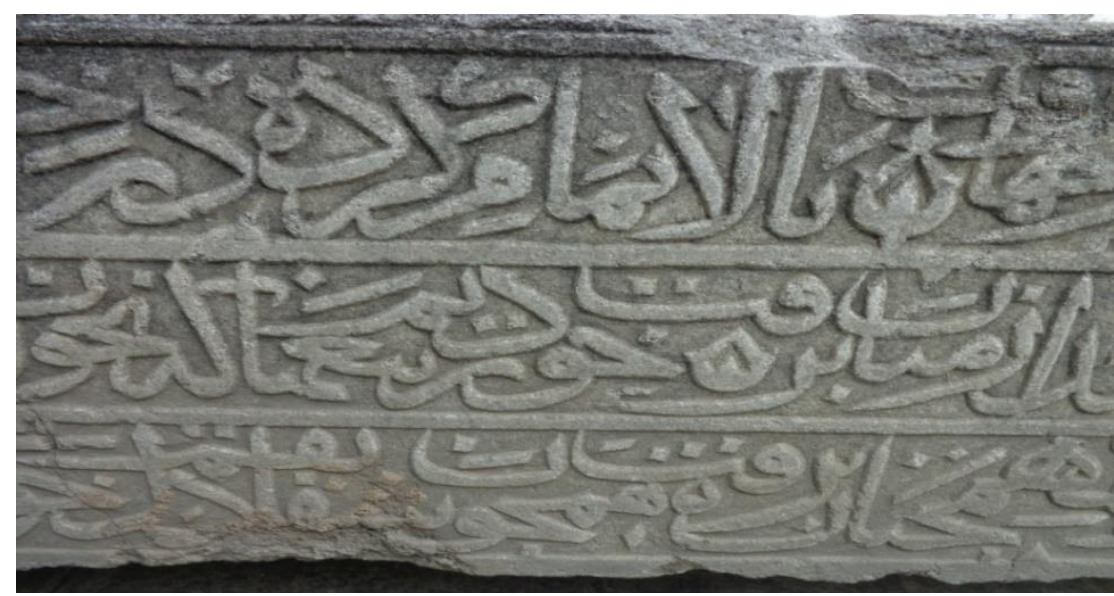

Pl. (1C): Details of the inscription on the long northern side of the stone structure

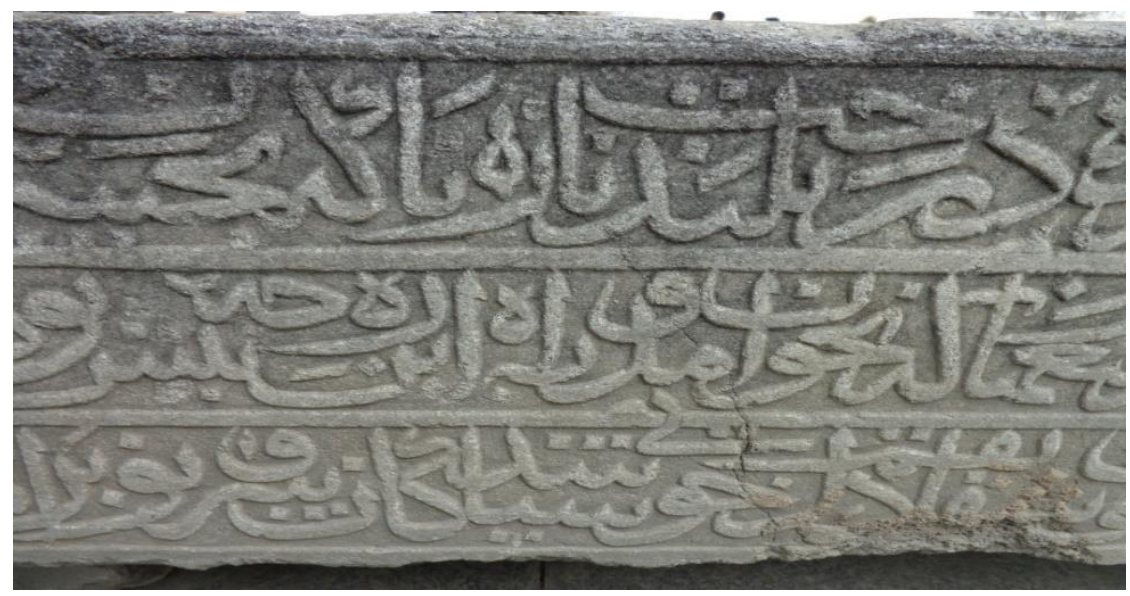

Pl. (1D): Details of the inscription on the long northern side of the stone structure

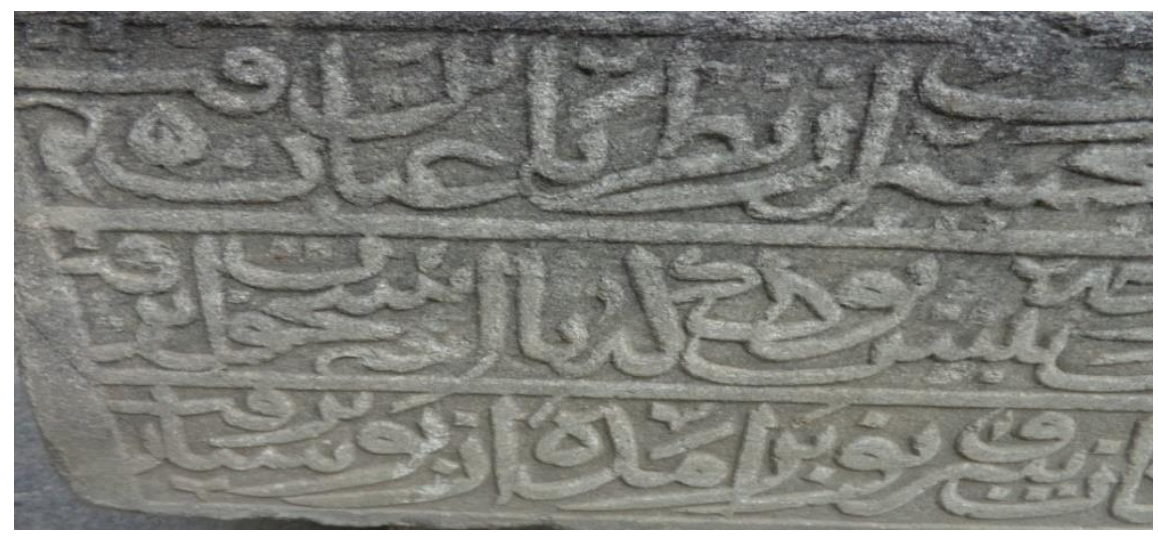

Pl. (1E): Details of the inscription on the long northern side of the stone structure 


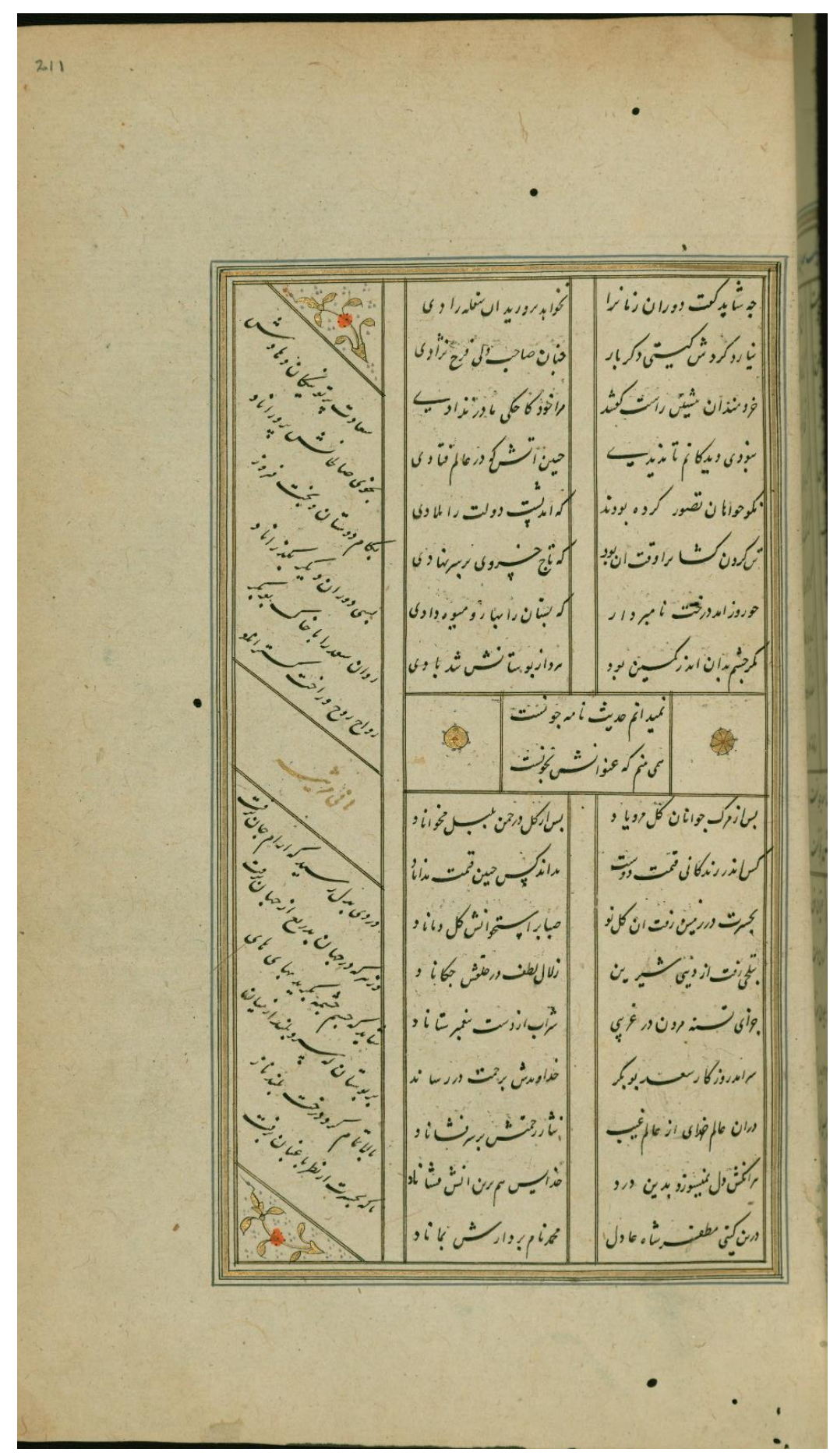

Pl (1F) Writings, the Walters Art Museum, Register No. w.617, sheet 211 obverse 


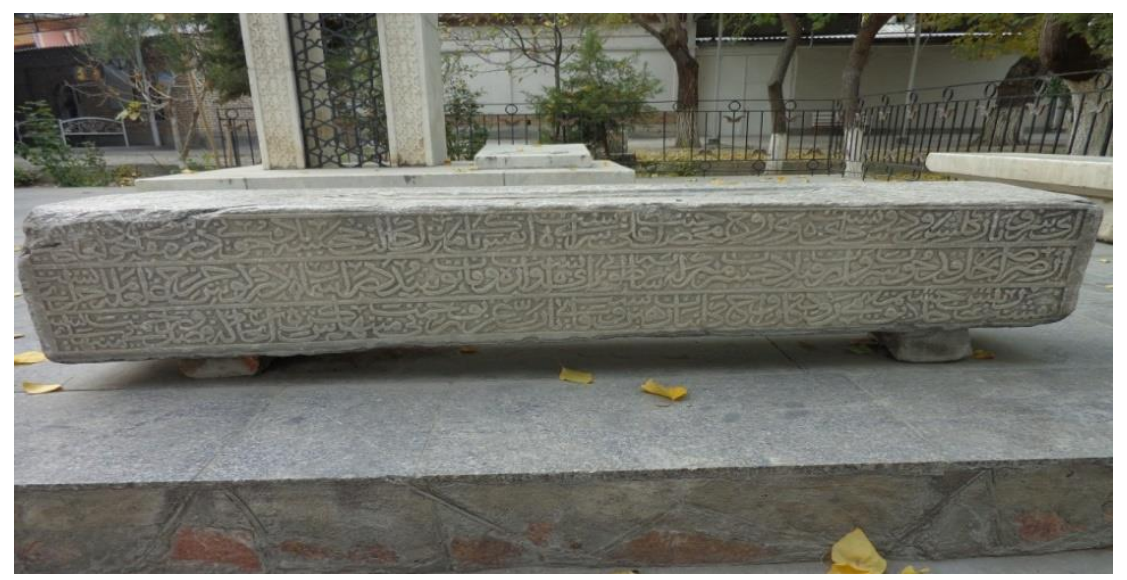

Pl. (2): The inscription on the southern side of the stone structure

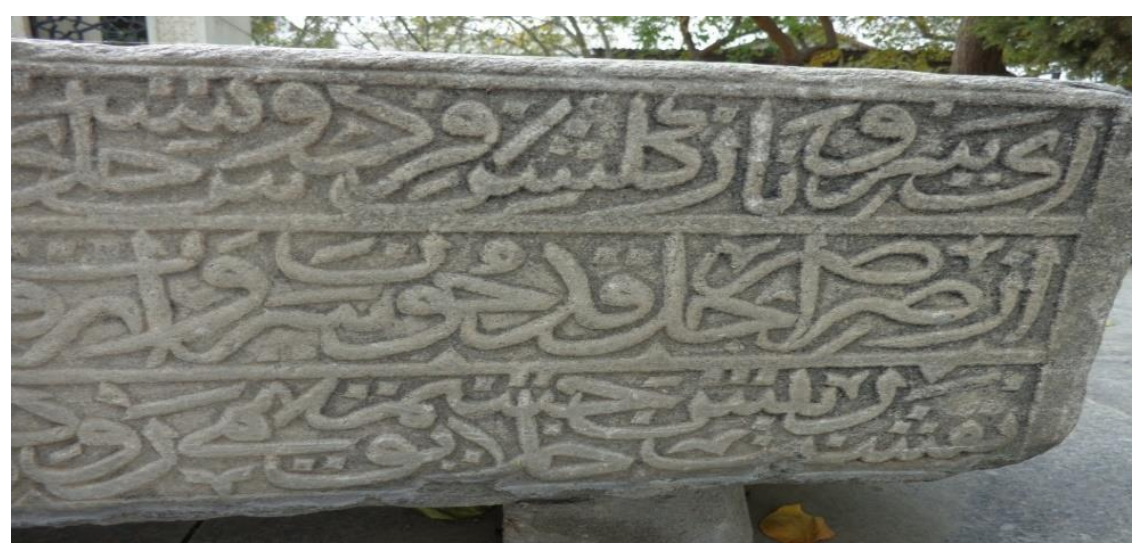

Pl. (2A): Details of the inscription on thelong southern side of the stone structure

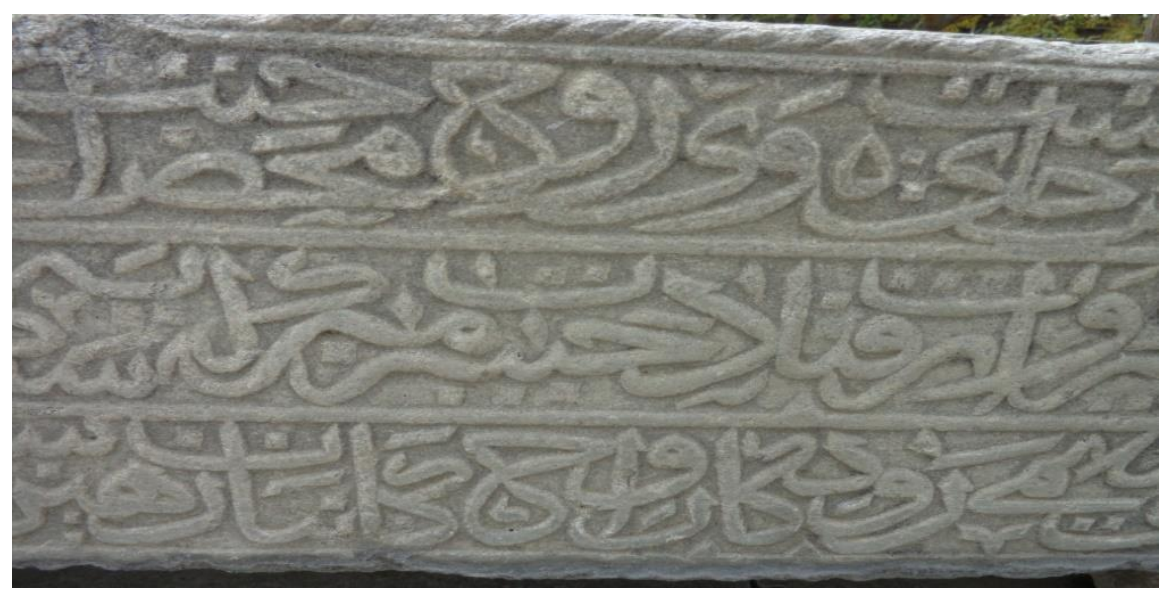

Pl. (2B): Details of the inscription on the long southern side of the stone structure 
A Stone Structure Dated 827 AH /1424 AD in Kokand, Central Asia: A Study on Form and Content

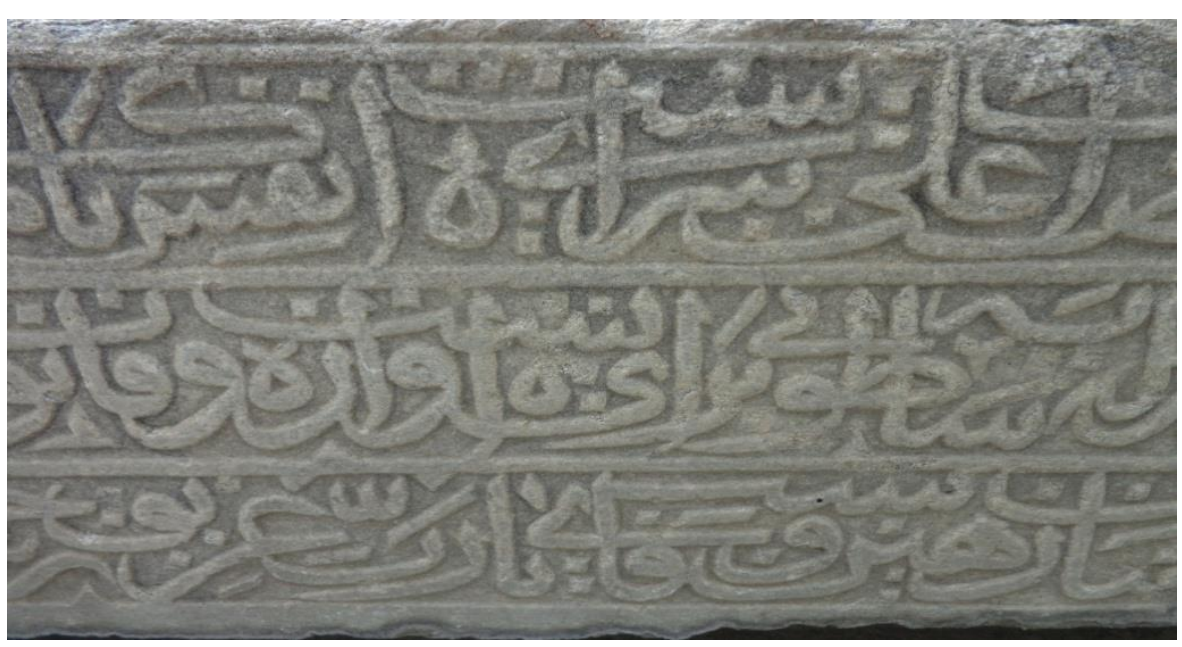

Pl. (2C): Details of the inscription on the long southern side of the stone structure

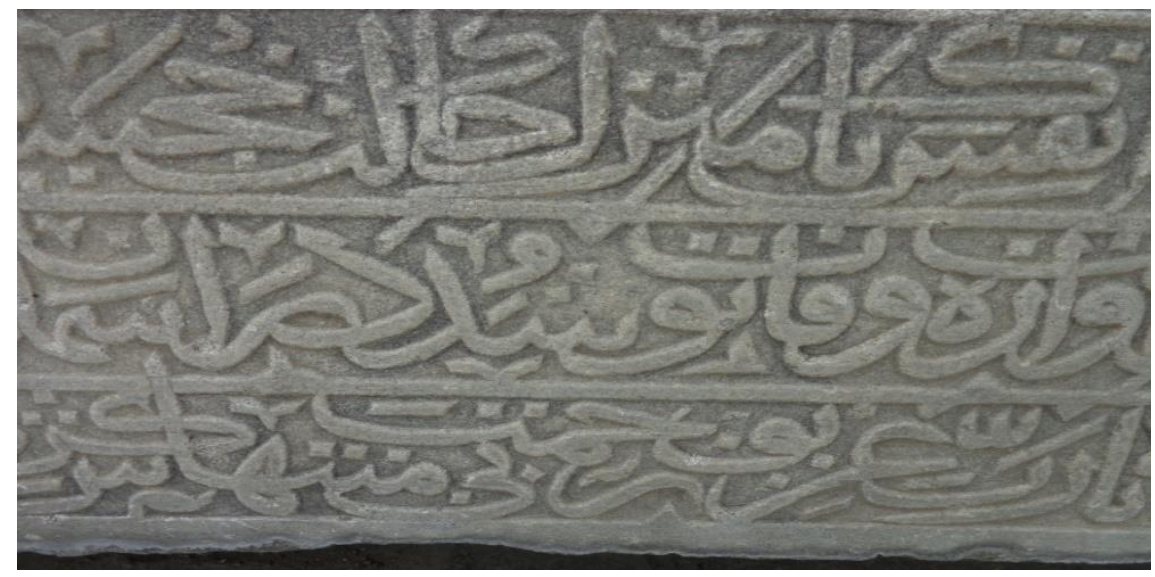

Pl. (2D): Details of the inscription on the long southern side of the stone structure

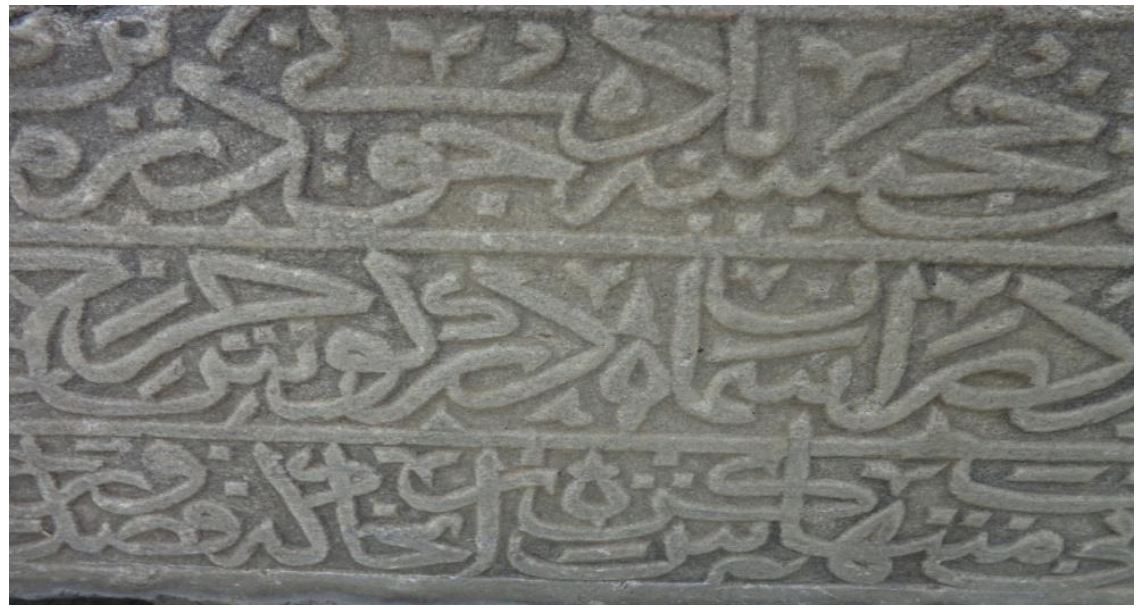

Pl. (2E): Details of the inscription on the long southern side of the stone structure 


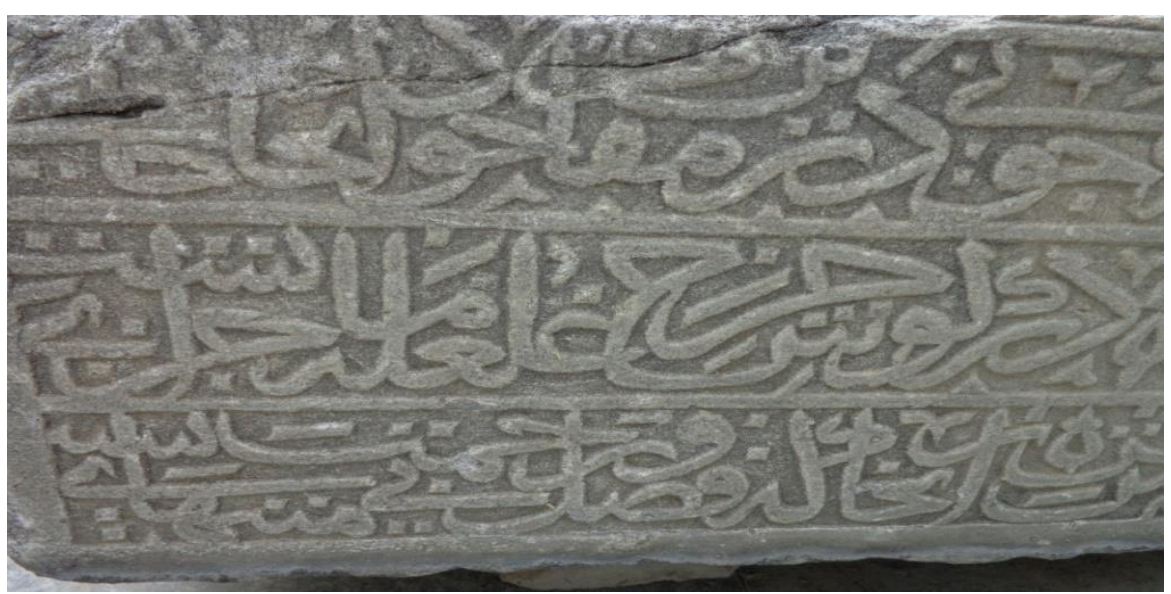

Pl. (2F): Details of the inscription on the long southern side of the stone structure

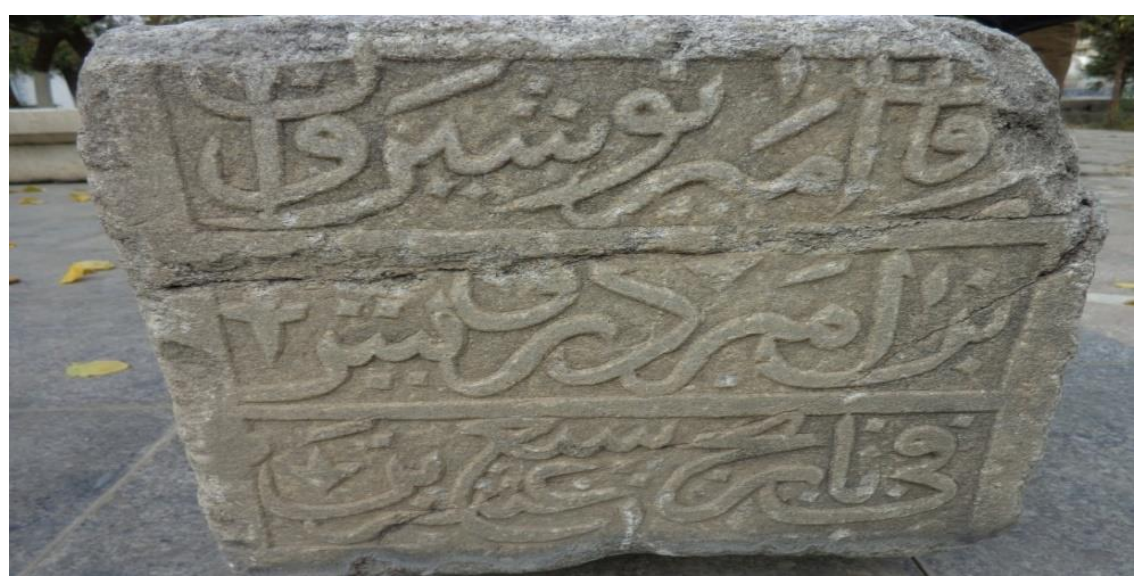

Pl. (3): The inscription on the short western side of the stone structure

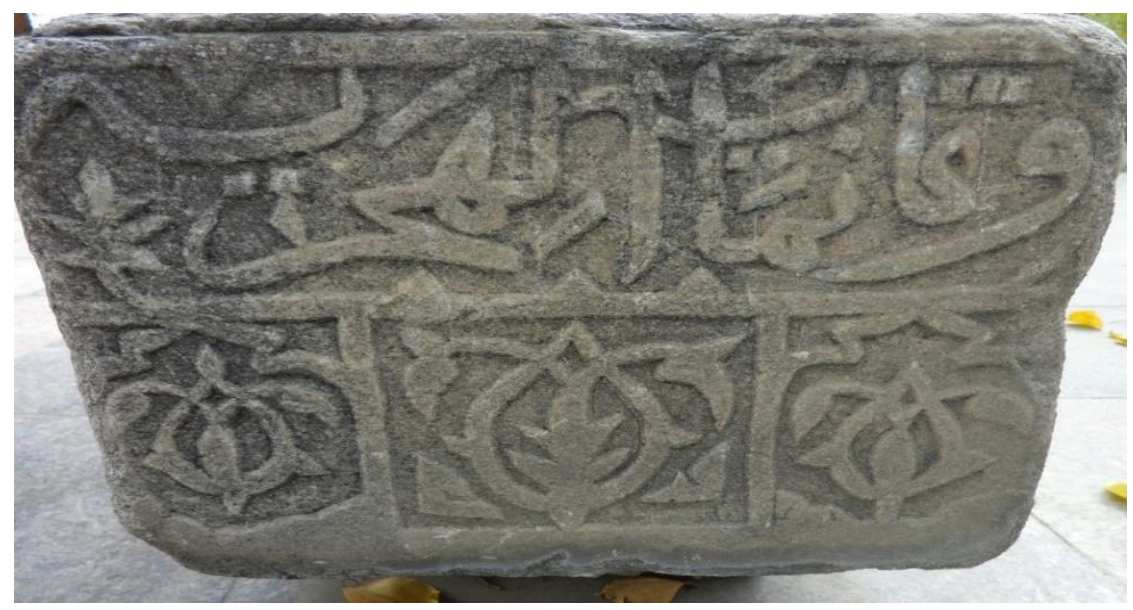

Pl. (4): The inscription on the short eastern side 


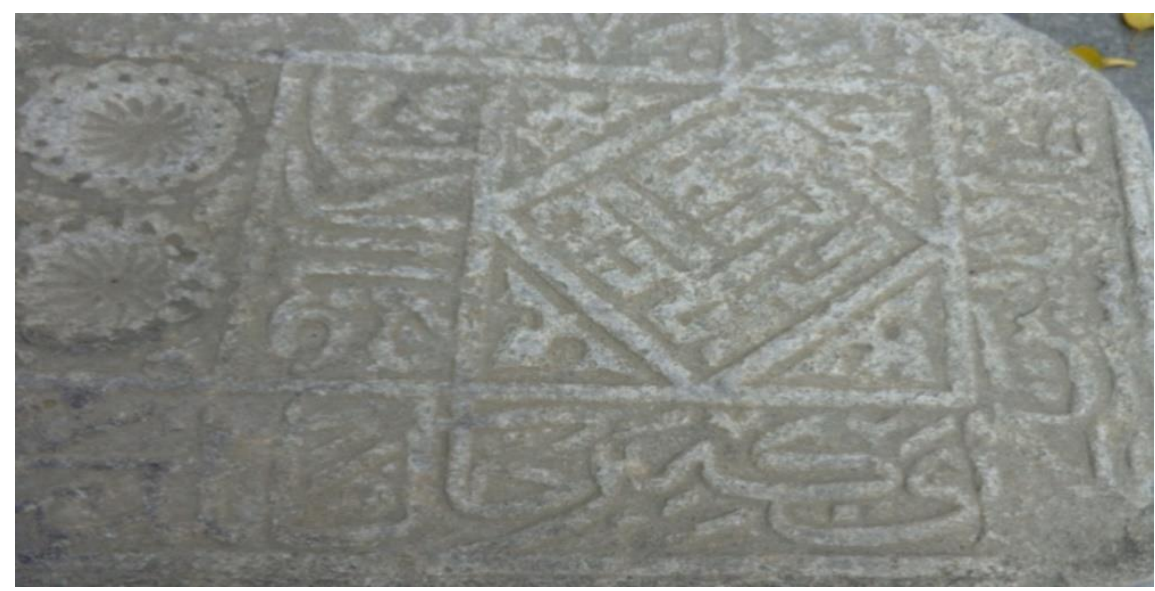

Pl. (5): The inscription on the internal surface of the stone structure

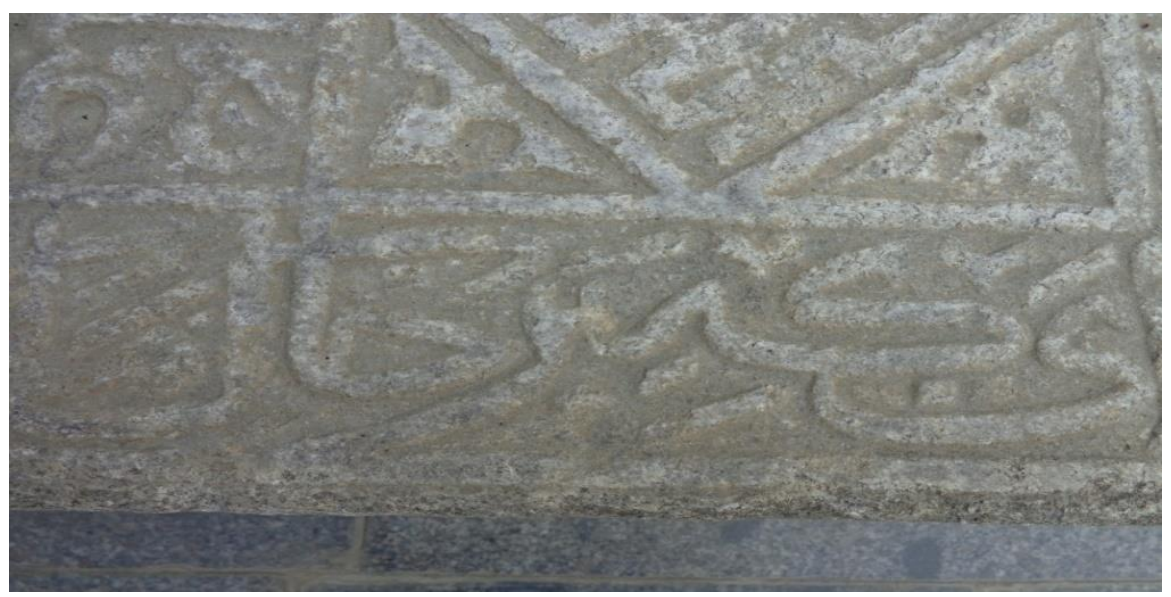

Pl. (5A): Details of the inscription on the internal surface of the structure

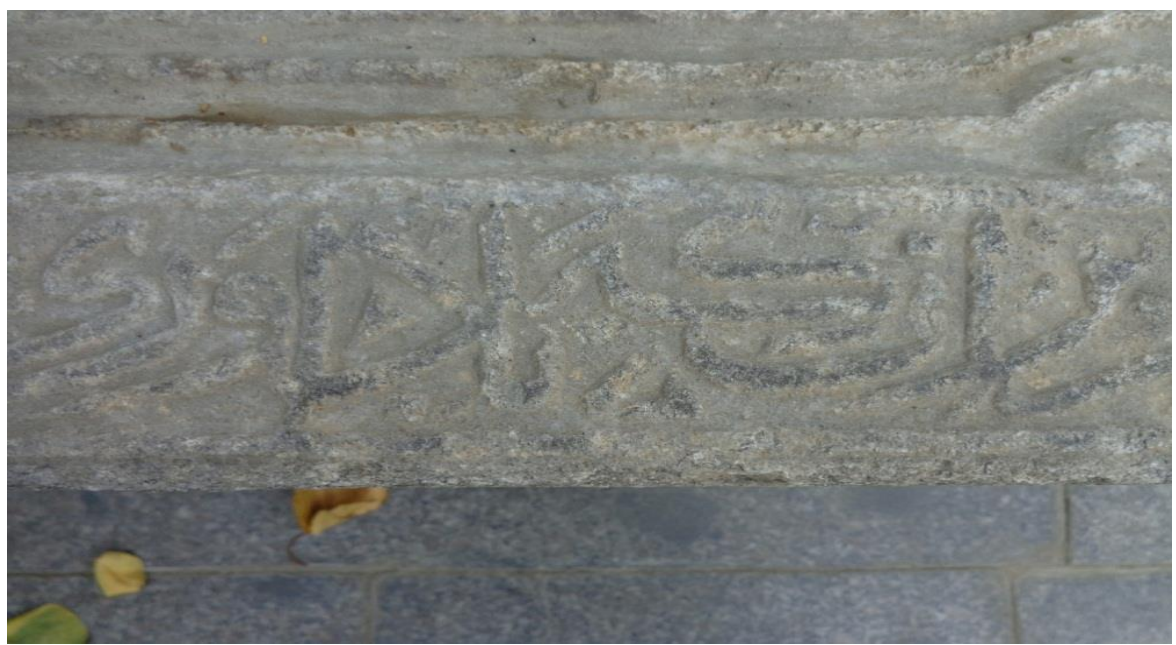

Pl. (5B): Details of the inscription on the internal surface of the structure 


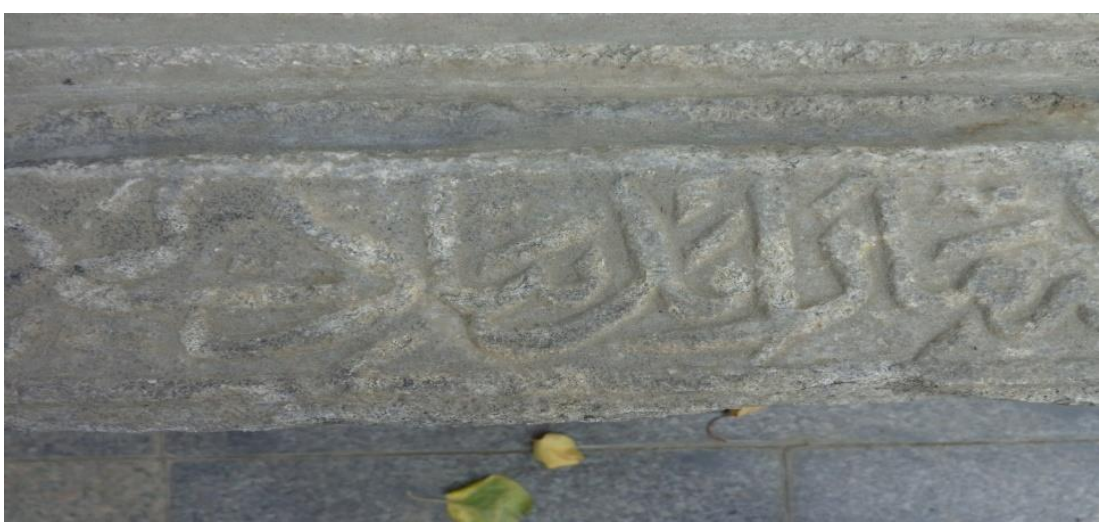

Pl. (5C): Details of the inscription on the internal surface of the structure

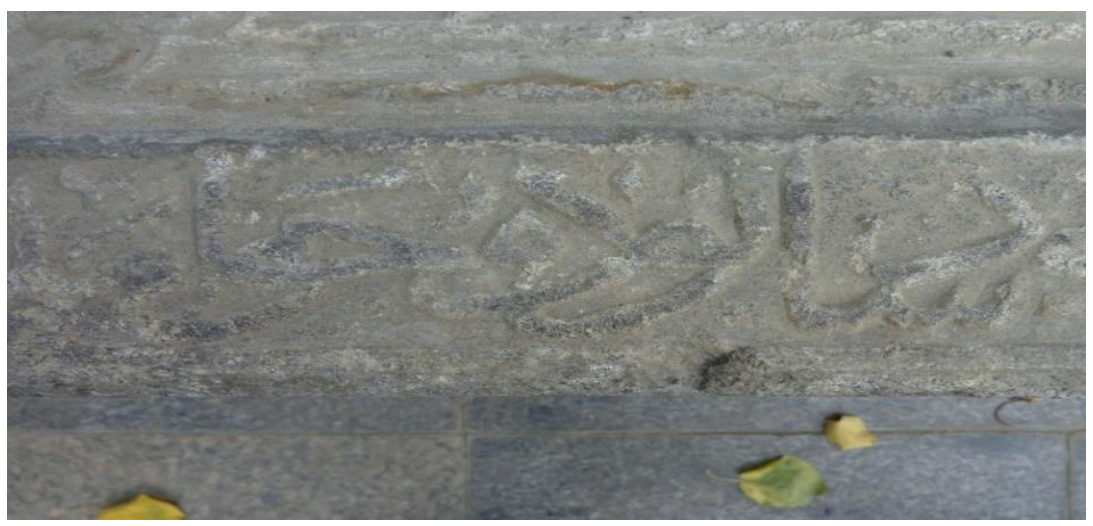

Pl. (5D): Details of the inscription on the internal surface of the structure

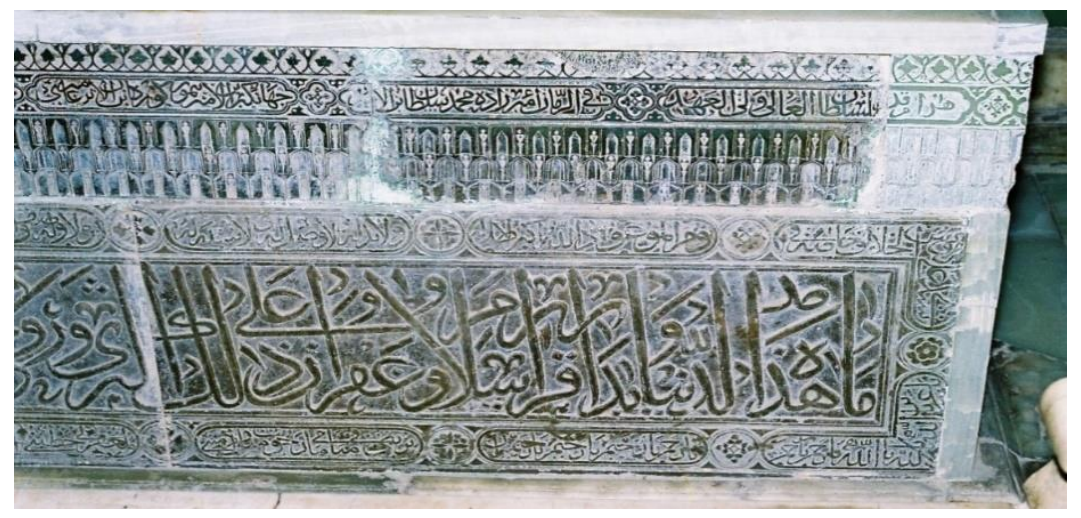

( plate 6 )Writings on the long northern side of the structure of Amir Zada Mohamed Sultan 
A Stone Structure Dated 827 AH /1424 AD in Kokand, Central Asia: A Study on Form and Content

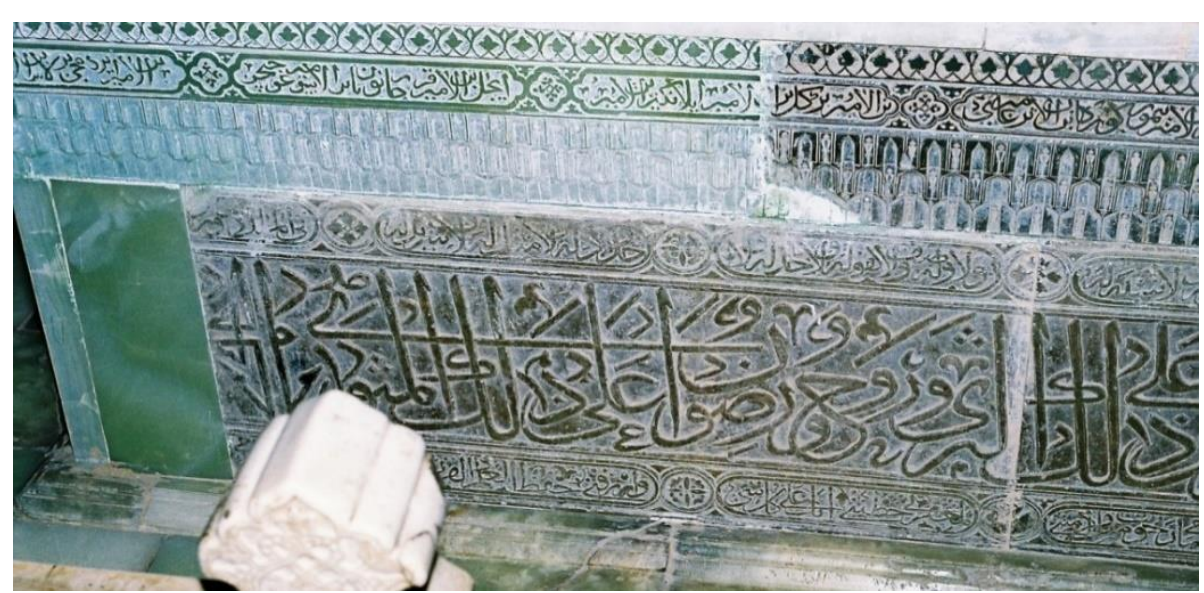

( Plate 6a )Writings on the long northern side of the structure of Amir Zada Mohamed Sultan

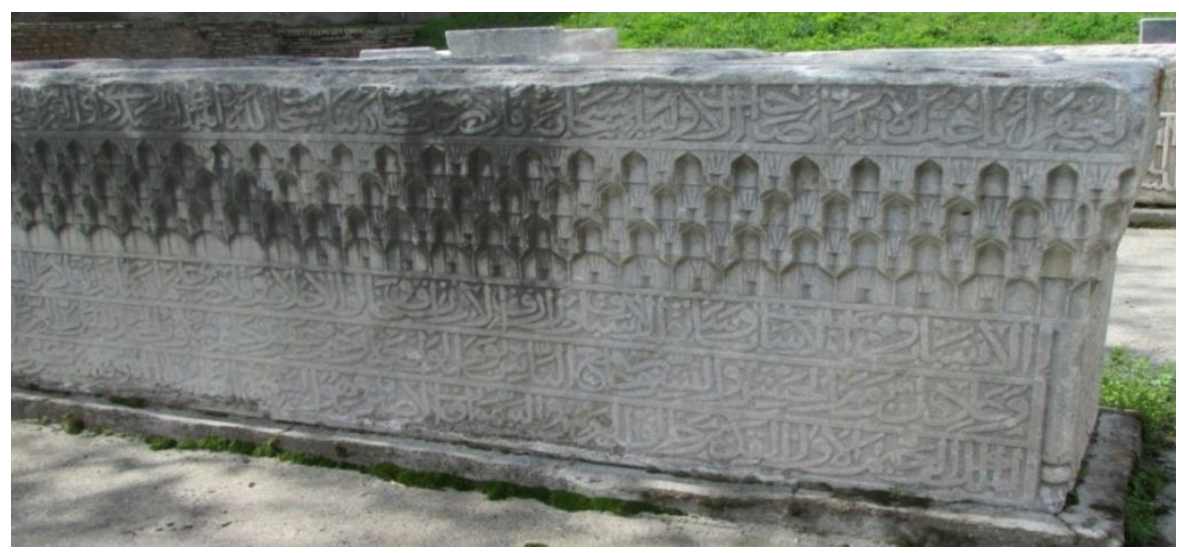

( Plate 7 ) The long western side of the structure of Emir Hamza Ibn Tugha Bugha 833AH.

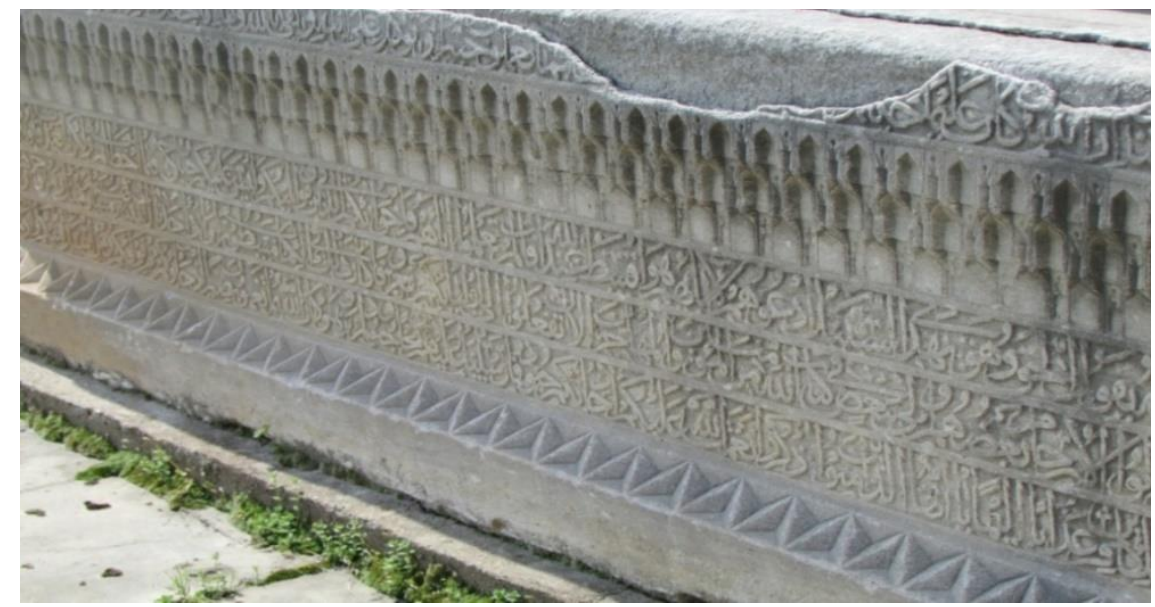

( Plate 8 )Details of the long eastern of Sultan Ibrahim Bahadur ibn Jihan Shah 